\title{
Identification and Confirmation of SSR Marker Tightly Linked to the Ti Locus in Soybean [Glycine max (L.) Merr.]
}

\author{
Jongil Chung \\ Department of Agronomy, Gyeongsang \\ National University, Chinju, \\ Republic of Korea
}

\section{Introduction}

Soybean [Glycine max (L.) Merr.,] is considered a high quality source of oil and protein for food and feed. However, the several antinutritional factors (lipoxygenase, trypsin inhibitor, lectin, and P34 allergen protein) present in raw mature soybean seeds. Soybean Kunitz trypsin inhibitor (KTI) protein has been proposed as one of the major antinutritional factor (Westfall and Hauge, 1948). KTI protein is a small, monomeric and non-glycosylated protein containing 181 amino acid residues. This $21.5 \mathrm{kDa}$ non-glycosylated protein was first isolated and crystallized from soybean seeds by Kunitz (1945). KTI protein can cause the induction of pancreatic enzyme hypersecretion and a fast stimulation of pancreas growth, which is histologically described as pancreatic hypertrophy and hyperplasia (Liencer, 1995). Also, KTI may cause unfavorable physiological effects (Vasconcelos et al., 2001) and decrease weight gain in animals (Palacios et al., 2004). Proper heat processing is required to destroy KTI protein. However, excessive heat treatment may lower amino acid availability. The genetic removal of the KTI protein will improve the nutritional value of soybean. From the USDA germplasm collection, two soybean accessions (PI157440 and PI196168) lacking the KTI protein have been identified (Orf and Hymowitz, 1979). Based on the availability of soybean null lines lacking the KTI protein, it was suggested that KTI protein is not essential for soybean growth or development. Five electrophoretic forms of KTI have been discovered. The genetic control of four forms, $\mathrm{Ti}{ }^{a}, \mathrm{Ti}{ }^{b}, \mathrm{Ti}{ }^{c}$, and $\mathrm{Ti}{ }^{d}$, has been reported as a codominant multiple allelic series at a single locus (Singh et al., 1969; Hymowitz and Hadley, 1972; Orf and Hymowitz, 1979). Orf and Hymowitz (1979) found that the fifth form does not exhibit a soybean trypsin inhibitor-A2 band and is inherited as a recessive allele designated $t i$. Studies of amino acid and nucleotide sequences of polymorphic variants of KTI have revealed that there is a large sequence differences in nine amino acid residues between $T i^{a}$ and $T i^{b}$ (Song et al., 1993; Wang et al., 2004). Each $T i c$, Ti ${ }^{d}$ and $T i^{e}$ differ by only one amino acid from $\mathrm{Ti}{ }^{a}$ type and $\mathrm{Ti} f$ differs by one amino acid from $\mathrm{Ti}{ }^{b}$ type (Wang et al., 2004). The Ti locus has been located on linkage group 9 in the classical linkage map of soybean (Hildebrand et al., 1980; Kiang, 1987), which is integrated in molecular linkage map A2 (chromosome number 8) of the USDA/Iowa State University soybean molecular linkage map (Cregan et al., 1999). 
DNA markers have become fundamental tools for research involving soybean improvement programs. Microsatellites or simple sequence repeat (SSR) markers are highly polymorphic, abundant, and distributed throughout the genome (Cregan et al., 1999). With the development and public release of SSR primers, SSR markers have become available on molecular soybean linkage group (Cregan et al., 1999). Molecular markers tightly linked to desired genes are a valuable tool to detect genotypes of interest, saving time and resources. Marker assisted selection (MAS) using DNA markers instead of phenotypic assays reduces cost and increases the precision and efficiency of subsequent selection steps applied in breeding. To date, detection of the KTI protein free genotypes has been based on SDS-PAGE gel electrophoresis analysis of crude protein from mature seeds, however, with this method, test samples are restricted to proteins from mature soybean seeds. This is a time-consuming process, which is not possible in the early seedling stages of the corresponding population. SSR markers tightly linked to the Ti locus were identified and confirmed in soybean populations for marker assisted selection. If a marker linked to the Ti locus can be confirmed, then selection for KTI protein free genotypes might be performed at early seedling stages with relative ease.

\section{Identification of SSR marker}

\subsection{Plant genotypes}

Soybean genotype C242 (clark derived near isogenic line) has the $t i$ allele and lacks a soybean kunitz trypsin inhibitor. C242 was a generous gift from J. Specht, professor of Agronomy, University of Nebraska-Lincoln, USA. Cultivar Jinpumkong2 and Clark has kunitz trypsin inhibitor protein band (TiTi). Two mapping populations were developed. Population 1 was derived from a cross between cultivar Jinpumkong2 and C242. Population 2 was made from a mating between cultivar Clark and C242. The $\mathrm{F}_{1}$ plants from two populations were grown in the greenhouse to produce $F_{2}$ seeds.

\subsection{Determination of kunitz trypsin inhibitor genotype}

$98 \mathrm{~F}_{2}$ seed from $\mathrm{F}_{1}$ plants for population 1 and $243 \mathrm{~F}_{2}$ seed from $\mathrm{F}_{1}$ plants for population 2 was analysed electrophoretically to determine the presence (SKTI- ' + ' ) or absence (SKTI'null ' ) of kunitz trypsin inhibitor. A piece of cotyledon from each $\mathrm{F}_{2}$ seed was removed and the remaining embryo germinated to given a $\mathrm{F}_{2}$ mapping population. The separated cotyledon tissue was incubated for $30 \mathrm{~min}$ (room temperature) in $1 \mathrm{ml}$ Tris- $\mathrm{HCl}, \mathrm{pH} 8.0$, containing $1.56 \% \mathrm{v} / \mathrm{v} \beta$-mercaptoethanol. After centrifugation, $50 \mu \mathrm{l}$ of the supernatant were added to an equivalent amount of $5 \mathrm{X}$ sample buffer $[10 \% \mathrm{w} / \mathrm{v}$ sodium dodecyl sulphate (SDS), $50 \% \mathrm{v} / \mathrm{v}$ glycerol, $1.96 \% \mathrm{v} / \mathrm{v} \beta$-mercaptoethanol, $1 \mathrm{M}$ Tris- $\mathrm{HCl}, \mathrm{pH}$ 6.8]. The samples were boiling at $97^{\circ} \mathrm{C}$ for $5 \mathrm{~min}$ and then centrifuged. Two microlitre of the supernatant were used for electrophoresis on $12 \%$ acrylamide SDS polyacrylamide gel electrophoresis (SDS-PAGE) medium gels in Owl Separation Systems. Inc(Model: P9DS, Portsmouth, NH USA). Electrophoresis was practiced at $120 \mathrm{~V}$ for $7 \mathrm{hr}$. Gels were stained overnight in an aqueous solution of $0.25 \mathrm{~g}$ coomassie brilliant blue R250, 10\% acetic acid, $45 \%$ methanol and destaining solution (5\% acetic acid, $14 \%$ methanol) for several hours. A Wide-Range SDS-PAGE molecular mass standard (Sigma MarkerTM, Product Code : M4038) containing the $21.5 \mathrm{kDa}$ soybean trypsin inhibitor protein, was used to aid recognition of samples lacking the kunitz trypsin inhibitor. 


\subsection{DNA extraction and DNA marker analysis}

$\mathrm{F}_{2}$ seeds tested for kunitz trypsin inhibitor protein were planted in the field on May, 2004. Young leaves were collected from the 94 individual $\mathrm{F}_{2}$ plants germinated among $98 \mathrm{~F}_{2}$ seeds and parent plants in population 1 . In population 2 , random $97 \mathrm{~F}_{2}$ seeds among $243 \mathrm{~F}_{2}$ seeds were planted in the greenhouse on April, 2005. Young leaves were collected from the 94 individual $\mathrm{F}_{2}$ plants. Genomic DNA was extracted from finely ground leaf tissue by means of a modified CTAB procedure (Saghai Maroof et al., 1984). For the analysis of random amplified polymorphic DNA (RAPD) markers, One-thousand 10-mer oligonucleotide primers were obtained from Operon Technologies (Alameda, U.S.A). For the analysis of simple sequence repeat (SSR) marker, total 35 SSR primers were selected from the A2 soybean molecular linkage map (Cregan et al., 1999) that contains Ti locus. Satt primers selected were synthesized by Bioneer, Inc. (Korea). For the analysis of amplified fragment length polymorphic (AFLP) markers, 342 primer sets were used. Amplification and electrophoresis for RAPD, SSR, and AFLP markers was performed as described by Kim et al., (2003). Based on the results of $F_{1}$ seed genotype for kunitz trypsin inhibitor, the present and absent bulk populations from $\mathrm{F}_{2}$ plant population were made (Michelmore et al., 1991). The present and absent bulk population contained twenty $F_{2}$ individuals each, which were selected on the basis of the kunitz trypsin inhibitor protein electrophoresis, respectively. RAPD, SSR, and AFLP markers were used in population 1. Only the markers linked in population 1 including $T i$ locus were used in population 2 .

\subsection{Genetic linkage analysis}

Primers that distinguished the bulks and the parents were tested on the entire $\mathrm{F}_{2}$ population. Marker (RAPD, AFLP, and SSR) data obtained from $94 \mathrm{~F}_{2}$ progenies of population 1 and 2 were used to construct genetic linkage map including $T i$ locus using the computer program MAPMAKER v. 3.0 (Lander et al., 1987). Markers were assigned to group using the "Group" command, with a LOD score of 4.0 and maximum recombination distance of $50 \mathrm{cM}$. Once markers were assigned to a given linkage group, the most linkage marker order within the group was determined using the "Compare" command. Marker orders within each linkage group were ascertained by use of "Ripple" command. Map distance (cM) were computed using the Kosambi (Kosambi, 1944) mapping function.

\subsection{Detection of Satt228 marker}

The banding patterns of kunitz trypsin inhibit protein (SKTI) that appeared in the parents and $F_{2}$ seeds from the cross between cultivar Jinpumkong2 and C242 (population 1) are shown in Figure 1. Jinpumkong2 parent had band in $21.5 \mathrm{KDa}$ position and the band was segregated in $\mathrm{F}_{2}$ seeds. The observed data for population 1 were 72 seeds with SKTI protein band and 26 seeds with no SKTI protein band $\left(\mathrm{X}^{2}=0.12, \mathrm{P}=0.70-0.80\right)$. For population 2 , the observed data were 185 seeds with SKTI protein band and 58 seeds with no SKTI protein band $\left(\chi^{2}=0.17, P=0.70-0.80\right)$. These observations fit the expected $3: 1$ ratio for the presence or absence of the SKTI protein band. Earlier studies have shown that the null phenotype of SKTI is inherited as a recessive allele designated $t i$ (Orf and Hymowitz, 1979). The segregation ratios of $3: 1$ observed in the $F_{2}$ seed (population 1 and 2) and the Chi-square values strongly suggest that kunitz trypsin inhibitor protein band is controlled by a single recessive gene. 


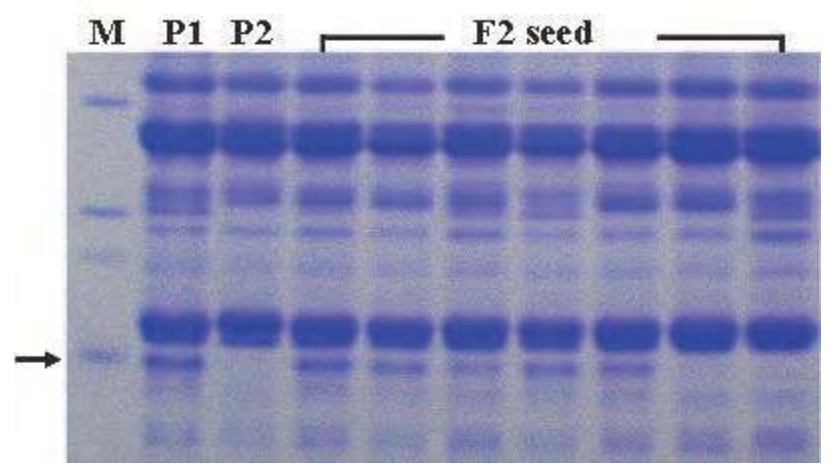

Fig. 1. Polyacrylamide gels of protein extracted from parents and $F_{2}$ seeds. P1 (Jinpumkong2) and P2 (C242) are parents and arrow points to the Kunitz trypsin inhibitor band $(21.5 \mathrm{KDa})$.

Of the 1,000 RAPD primers tested on two parents of population 1 (Jinpumkong2 and C242), approximately $12 \%$ (124) primers produced polymorphic DNA fragment differences between the parents. Only 35 primers were identified as being polymorphic between bulked DNA samples with SKTI protein and bulked DNA samples with no SKTI protein. Of those 35 primers, only 16 also exhibited polymorphism between parents. Among 342 primer sets of AFLP analysis, only 10 primers were shown polymorphism between parents. Three SSR primers (Satt409, Satt228 and Satt429) among 35 primers selected were shown polymorphism between parents. Total 48 markes (35 RAPD, 10 AFLP, and 3 SSR) were used to obtain segregation data from $94 \mathrm{~F}_{2}$ individuals of population 1 . Figure 2 represents some example of segregating DNA fragment for SSR markers (Satt228) in parents, bulked samples and $\mathrm{F}_{2}$ population.

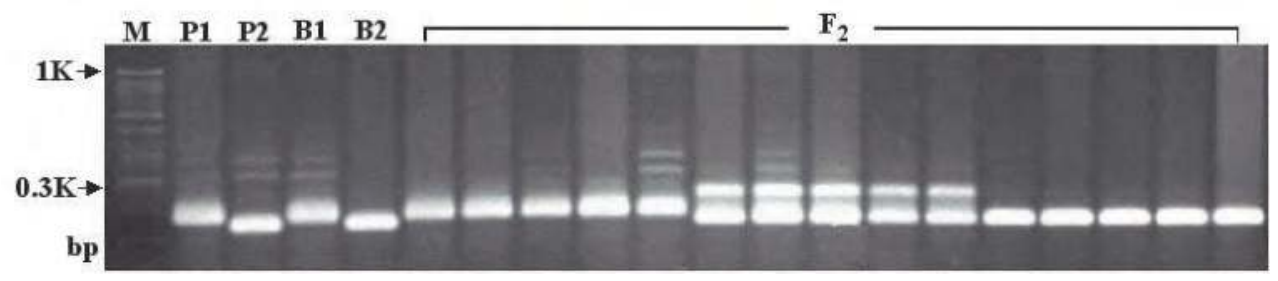

Fig. 2. Patterns of segregating DNA fragment for SSR primer Satt228 in parents, bulked samples, and $\mathrm{F}_{2}$ population. P1 is Jinpumkong2 (TiTi) and P2 is C242 (titi). B1 is bulked of present kunitz trypsin inhibitor protein individuals and B2 is bulked of absent individuals.

A genetic map was constructed from the 48 segregating DNA markers and Ti locus. A total 11 DNA markers (4 RAPD, 4 AFLP, and 3 SSR) and Ti locus was found to be genetically linked in population 1. Three SSR markers, Satt409, Satt228, and Satt429 linked with Ti locus within $10 \mathrm{cM}$ (Figure 3). Satt228 marker was very tightly linked with Ti locus at $0 \mathrm{cM}$. Three SSR markers linked with $\mathrm{Ti}$ locus in population 1 were applied in population 2. Only two SSR markers, Satt228 and Satt 409 were linked with Ti locus. Satt228 marker was linked with $\mathrm{Ti}$ locus in $3.7 \mathrm{cM}$ distance (Figure 3). The order and map distances of SSR markers and Ti locus differed between populations 1 and 2. 


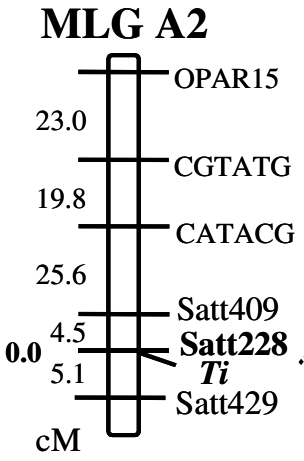

Population 1

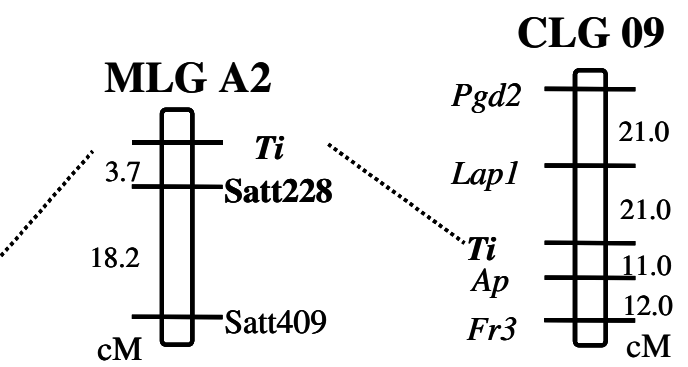

Population 2

Fig. 3. Molecular linkage map A2 (Cregan et al., 1999) of Ti locus defined using population 1 and population 2. Population 1 was derived from the cross of Jinpumkong2 (TiTi) and C242 (titi). Population 2 was derived from the cross of Clark (TiTi) and C242 (titi). Map was constructed using MAPMAKER/EXP (LOD 4.0 maximum distance $50 \mathrm{cM}$ ). Marker loci names are on the right and kosambi map distances are on the left. CLG09 is the classical linkage group 9 (Hildebrand et al., 1980; Kiang 1987).

\section{Confirmation of Satt228 marker}

\subsection{Screening of titi genotype using Satt228 marker}

Only two genotypes (PI 157440 and PI 196168) and two near isogenic lines (C242, W60) have been known as soybean genotypes with lacking Kunitz trypsin inhibitor protein (titi genotype). C242 is a near isogenic line derived from cultivar 'Clark' and W60 is a near isogenic line derived from cultivar 'William'.

Satt228 marker very tightly linked to $\mathrm{Ti}$ locus at distance of $0 \mathrm{cM}$ was used to screen germplasms with titi genotype (Kunitz trypsin inhibitor protein absent) for marker confimation and testing the possibility of marker-assisted selection (MAS). Amplification patterns obtained from Satt228 marker using genomic DNA of four soybean strains (PI157440, PI196168, W60, and C242) with titi genotype (Kunitz trypsin inhibitor protein absent) and three cultivars ('Jinpumkong2', 'Clark', and 'William') with TiTi genotype (Kunitz trypsin inhibitor protein present) are shown in Figure 4-1A. Also, polyacrylamide gel banding patterns of protein extracted from random 10 seeds of these seven germplasms used are shown in Figure 4-1B. TiTi genotypes ('Jinpumkong2', 'Clark', and 'William') had allele1, however, titi genotypes (PI196168, C242, W60 and PI157440) had allele2 in the result of PCR by Satt228 marker (Figure 4-1A). TiTi genotypes ('Jinpumkong2', 'Clark', and 'William') had $21.5 \mathrm{kDa}$ band that indicates Kunitz trypsin inhibitor protein, however titi genotypes (PI196168, C242, W60 and PI157440) did not have the band in of protein gel electrophoresis from the mature seed (Figure 4-1B). From the comparison of gel electrophoresis for Kunitz trypsin inhibitor protein (Figure 4-1B) and banding pattern amplified by Satt228 marker from the genomic DNA (Figure 4-1A), there was a strong agreement between protein band $(21.5 \mathrm{kDa})$ for Kunitz trypsin inhibitor protein and banding pattern by Satt228 marker. All TiTi genotypes ('Jinpumkong2', 'Clark', and 'William') which shown $21.5 \mathrm{kDa}$ protein band in protein electrophoresis of mature seed had 
the allele1 amplified by Satt228 marker from the genomic DNA. However, all titi genotypes (PI196168, C242, W60 and PI157440) which shown no $21.5 \mathrm{kDa}$ protein band in electrophoresis of mature seed had allele2 amplified by Satt228 marker from the genomic DNA.
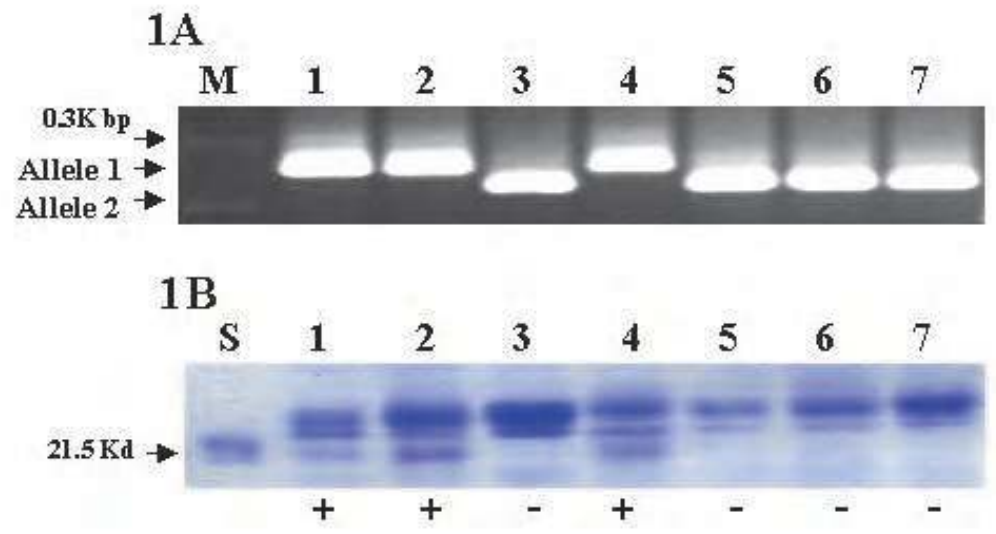

Fig. 4. Pattern of genomic DNA amplification by Satt228 marker using leaf tissue of germplasms (1A) and pattern of polyacrylamide protein gel electrpophoresis extracted from 10 random seeds harvestes (1B). M; molecular marker, S; Kunitz trypsin inhibitor protein (Sigma, product number: T6522 ). 1:Jinpumkong2(TiTi), 2:Clark (TiTi), 3:PI196168 (titi), 4: William (TiTi), 5: C242 (titi), 6: W60 (titi), 7: PI157440 (titi). +: present of KTI protein and -: absent of KTI protein.

Moraes et al. (2006) reported specific DNA marker designed to detect the absence of SKTI protein. For markers to be most useful in breeding programs, they should reveal polymorphism in different genetic backgrounds, which is referred to as marker validation (Sharp et al., 2001). Specific DNA marker designed to detect the absence of SKTI protein reported by Moraes et al. (2006) was not valid between germplasms of TiTi (SKTI protein present) and titi (SKTI protein absent) genotype used in this study. No polymorphism was observed among germplasms used. However, Cosegregation between allele of Satt228 marker and presence or absence of SKTI protein in several soybean germplasms of TiTi and titi genotyes was observed (Figure 4-1A and 1B). This results indicate that selection of germplasms or lines with lacking Kunitz trypsin inhibitor protein is possible by Satt228 marker analysis.

\subsection{Confirmation of Satt228 marker in four different soybean populations}

Cosegregation between Satt228 marker and Ti locus was confirmed in four different populations. Two cultivars (Jinpumkong2, Hannamkong) and two landraces (GS06, 20M183) have Kunitz trypsin inhibitor protein (TiTi genotype) in their mature seeds. The C242 parent is a clark-derived near isogenic line and does not have Kunitz trypsin inhibitor protein (titi genotype) in the mature seeds. Four different populations were developed. Four female parents (Jinpumkong2, Hannamkong, GS06, 20M183) and one male parent C242 were crossed in the greenhouse in June 2002. $F_{1}$ seeds from the cross of Jinpumkong $2 x$ C242, Hannamkong x C242, GS06 x C242, and 20M183 x C242 were obtained and planted in 
the greenhouse. $F_{2}$ seeds per each cross were harvested from several $F_{1}$ plants in November 2002. All $F_{2}$ seeds per each cross were planted in the field in May 2003. $F_{2}$ plants per each cross were harvested individually. Random $\mathrm{F}_{3}$ seeds from individual $\mathrm{F}_{2}$ plant per each cross were tested by SDS-PAGE protein analysis to detect Kunitz trypsin inhibitor protein. Individual $\mathrm{F}_{2}$ plants ( $\mathrm{F}_{3}$ seeds) with free Kunitz trypsin inhibitor protein (titi genotype) per each cross were planted in the greenhouse and harvested individually in June 2004. Random $\mathrm{F}_{4}$ seeds from individual $\mathrm{F}_{3}$ plant harvested per each cross were planted in the field in June 2004. At maturity, $F_{4}$ plants $\left(F_{5}\right.$ seeds) were harvested individually per each cross in November 2004. Random $\mathrm{F}_{5}$ seeds from individual $\mathrm{F}_{4}$ plant harvested per each cross were planted in the field in May 2005. Five parents and individual $F_{5}$ plants per each cross were used to confirm the SSR marker tightly linked to Ti locus. Agronomical traits except for the Kunitz trypsin inhibitor protein were not considered in each generation. The pedigree for the development of the four populations lacking the Kunitz trypsin inhibitor protein is summarized in Figure 5.
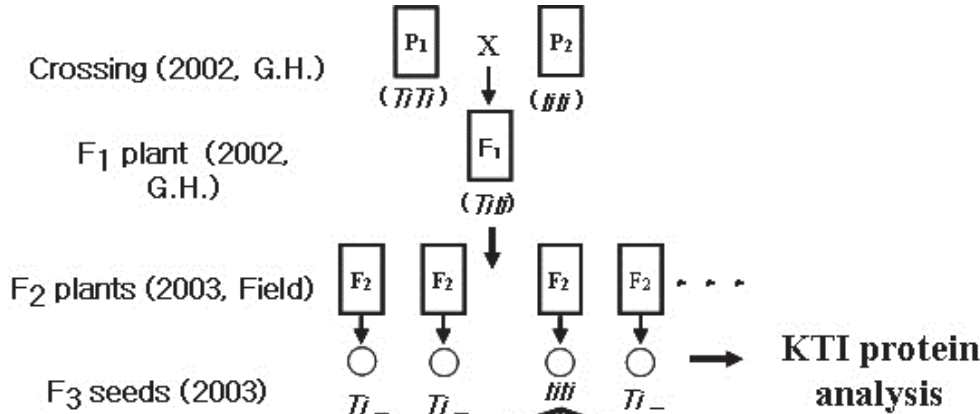

$\mathrm{F}_{3}$ plants (2004, G.H.)
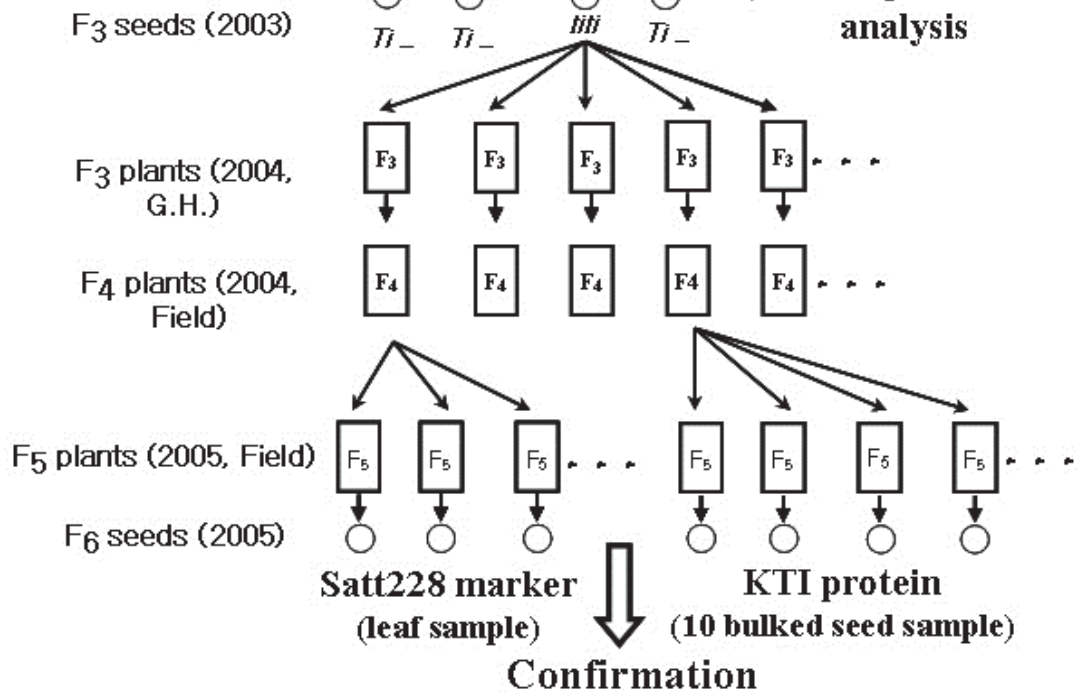

Fig. 5. The pedigree of the four population development to confirm cosegregation between marker Satt228 and the Ti locus. $F_{2}$ plants lacking the KTI protein from each population were selected and advanced to the next generation. All $\mathrm{F}_{5}$ plants have the titi genotype (lacking Kunitz trypsin inhibitor protein). G.H is greenhouse. 
Segregation patterns of genomic DNA amplification by the Satt228 marker using young leaf tissue of four parents and several individual $F_{5}$ plants $(A, C, E, G)$ and patterns of polyacrylamide protein gel using protein extracted from 10 random seeds of four parents and individual $\mathrm{F}_{6}$ harvested $(\mathrm{B}, \mathrm{D}, \mathrm{F}, \mathrm{H})$ are shown in Figure 6 . The bands amplified by the Satt228 marker are clearly detecting the AA and BB genotypes. The seed protein band by the SDS-PAGE is a little different in color density according to each population, staining time of Coomassie blue and protein content. However, the detection of the presence or absence of the Kunitz trypsin inhibitor protein was very clear because the Kunitz trypsin inhibitor protein is controlled by single gene and is not influenced by environment.

Satt228 marker analysis was conducted on the genomic DNA of the parents and the 273 individual $\mathrm{F}_{5}$ plants lacking the Kunitz trypsin inhibitor protein derived from the cross of 'Jinpumkong2' (TiTi) and C242 (titi). After harvesting at maturity, SDS-PAGE electrophoresis using crude protein extracted from ten random $\mathrm{F}_{6}$ seeds of each $\mathrm{F}_{5}$ plants and parents was performed to detect Kunitz trypsin inhibitor protein of size $21.5 \mathrm{kDa}$. DNA banding pattern of the Satt228 marker and polyacrylamide gel banding patterns of the protein is shown in Figure 6 (A and B). The $\mathrm{P}_{1}$ parent (Jinpumkong2) had the AA genotype (allele 1) and the $\mathrm{P}_{2}$ parent (C242) had BB genotype (allele 2) for Satt228 marker. All 273 individual $\mathrm{F}_{5}$ plants were shown only to have the BB genotype (A of Figure 6). This indicated all $273 \mathrm{~F}_{5}$ progenies had the titi genotype and contained no Kunitz trypsin inhibitor protein. Also, the $\mathrm{P}_{1}$ parent had Kunitz trypsin inhibitor protein of $21.5 \mathrm{kDa}$ size and the $\mathrm{P}_{2}$ parent did not have the KTI protein (B of Figure 6). All 273 individual $\mathrm{F}_{5}$ plants did not have the Kunitz trypsin inhibitor protein of $21.5 \mathrm{kDa}$ size (B of Figure 6). Amplification patterns obtained from the Satt228 marker using genomic DNA of 17 individual $\mathrm{F}_{5}$ plants derived from the cross of Hannamkong (TiTi) and C242 (titi) and polyacrylamide gel banding patterns of protein extracted from the mixture of 10 random $\mathrm{F}_{6}$ seeds harvested from each $F_{5}$ plant are shown in Figure $6(C$ and $D)$. The $P_{1}$ parent (Hannamkong) had a AA genotype while the $\mathrm{P}_{2}$ parent $(\mathrm{C} 242)$ had the $\mathrm{BB}$ genotype $(\mathrm{C}$ of Figure 6). All 17 individual $F_{5}$ plants derived from cross of Hannamkong and $C 242$ showed only the BB genotype pattern for Satt228 marker analysis (C of Figure 6). This indicated all $17 \mathrm{~F}_{5}$ progenies had the titi genotype and no Kunitz trypsin inhibitor protein. For the protein analysis, the $\mathrm{P}_{1}$ parent had the $21.5 \mathrm{kDa}$ Kunitz trypsin inhibitor protein while the $\mathrm{P}_{2}$ parent did not have the KTI protein in polyacrylamide protein (D of Figure 6). All 17 individual $F_{5}$ plants did not have the $21.5 \mathrm{kDa}$ Kunitz trypsin inhibitor protein within their $\mathrm{F}_{6}$ seed samples (D of Figure 6). Amplification patterns by the Satt228 marker using genomic DNA of 45 individual $F_{5}$ plants derived from the cross of GS06 (TiTi) and C242 (titi) and polyacrylamide gel banding patterns of protein extracted from the mixture of 10 random $\mathrm{F}_{6}$ seeds harvested from each $\mathrm{F}_{5}$ plant are shown in Figure 6 (E and F). The $\mathrm{P}_{1}$ parent (GS06) had the AA genotype and the $\mathrm{P}_{2}$ parent $(\mathrm{C} 242)$ had the BB genotype (E of Figure 6). All 45 individual $\mathrm{F}_{5}$ plants derived from the cross of GS06 and C242 displayed only the BB genotype pattern for marker Satt228 (E of Figure 6). Also, the $\mathrm{P}_{1}$ parent had the $21.5 \mathrm{kDa}$ Kunitz trypsin inhibitor protein and the $\mathrm{P}_{2}$ parent did not have the KTI protein in polyacrylamide protein gel from mature seeds ( $\mathrm{F}$ of Figure 6). All 45 individual $\mathrm{F}_{6}$ seeds harvested from same individual $\mathrm{F}_{5}$ plants did not have Kunitz trypsin inhibitor protein of $21.5 \mathrm{kDa}$ size ( $\mathrm{F}$ of Figure 6). This indicated all $45 \mathrm{~F}_{5}$ progenies had the titi genotype and contained no Kunitz trypsin inhibitor protein. Using marker Satt228, amplification patterns from 56 individual $F_{5}$ plants derived from the cross of 20M183 (TiTi) and C242 (titi) and 


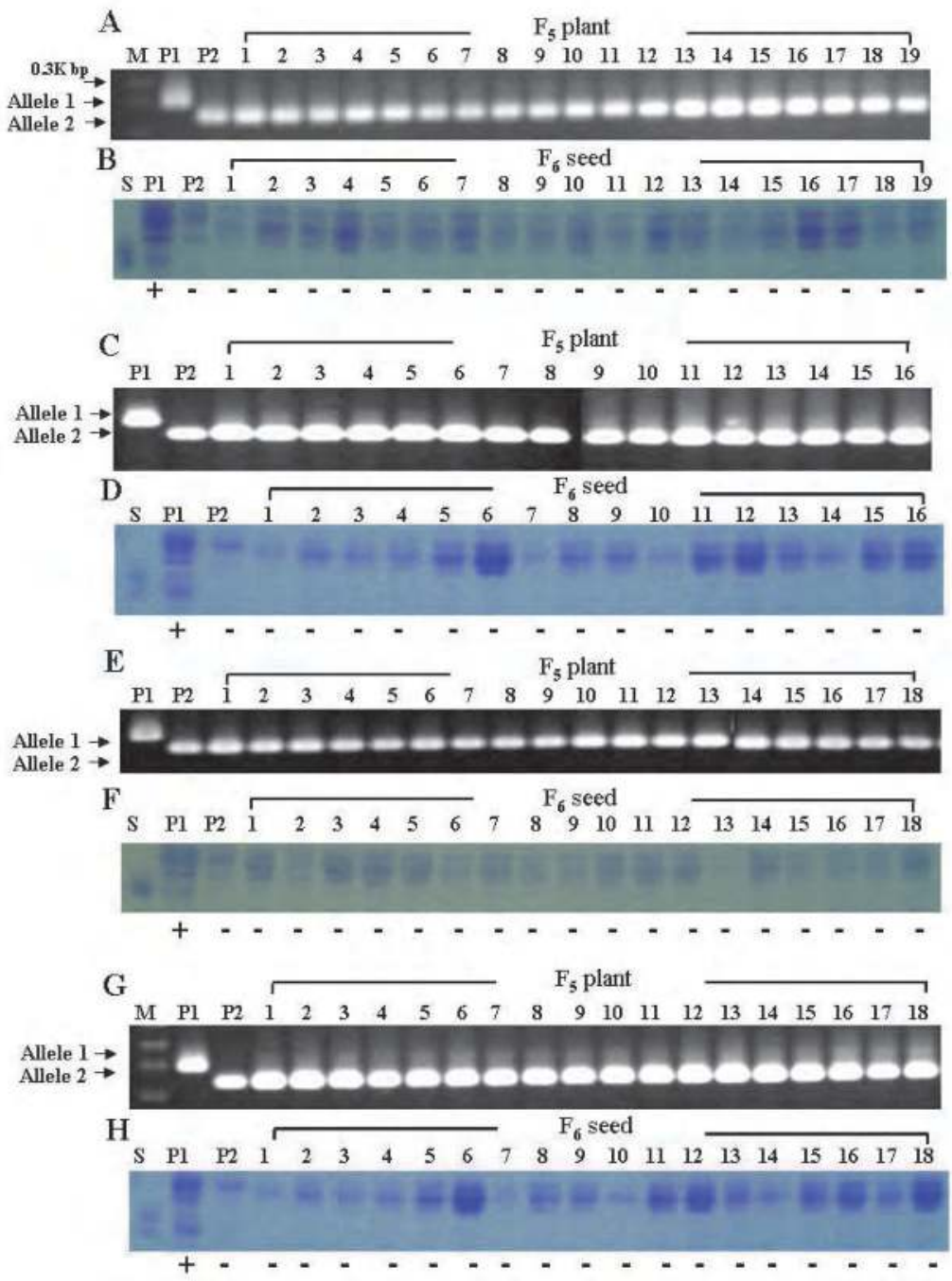

Fig. 6. Pattern of genomic DNA amplification by Satt228 marker using leaf tissue of parent and individual $F_{5}$ plants $(A, C, E, G)$ and pattern of polyacrylamide protein gel using protein extracted from parents and 10 random seeds of individual $\mathrm{F}_{6}$ seed harvested $(\mathrm{B}, \mathrm{D}, \mathrm{F}, \mathrm{H})$. A and B, P1: 'Jinpumkong2' and P2: C242; C and D, P1: 'Hannamkong' and P2: C242; E and F, P1:GS06 and P2: C242; G and H, P1:20M183 and P2: C242. M; molecular marker, S; Kunitz trypsin inhibitor protein (Sigma, product number: T6522 ), +; present of KTI protein, -; absent of KTI protein.

polyacrylamide gel banding patterns of protein extracted from the mixture of 10 random $\mathrm{F}_{6}$ seeds harvested from each $\mathrm{F}_{5}$ plant are shown in Figure $6(\mathrm{G}$ and $\mathrm{H})$. The $\mathrm{P}_{1}$ parent (20M183) had the AA genotype while the $\mathrm{P}_{2}$ parent (C242) had the BB genotype (G of Figure 6). All 56 individual $\mathrm{F}_{5}$ plants were shown only to have the $\mathrm{BB}$ genotype pattern for the Satt228 
marker (G of Figure 6). This indicated all $56 \mathrm{~F}_{5}$ progenies had the titi genotype and contained no Kunitz trypsin inhibitor protein. For the protein analysis the $\mathrm{P}_{1}$ parent had the Kunitz trypsin inhibitor protein of $21.5 \mathrm{kDa}$, while the $\mathrm{P}_{2}$ parent did not have the KTI protein $(\mathrm{H}$ of Figure 2). All 56 individual $\mathrm{F}_{5}$ plants did not have the $21.5 \mathrm{kDa}$ Kunitz trypsin inhibitor protein based upon their 10 random $\mathrm{F}_{6}$ seed samples ( $\mathrm{H}$ of Figure 6).

Segregation patterns of genomic DNA amplification by the Satt228 marker using young leaf tissue of four parents and several individual $F_{5}$ plants $(A, C, E, G)$ and patterns of polyacrylamide protein gel using protein extracted from 10 random seeds of four parents and individual $\mathrm{F}_{6}$ harvested $(\mathrm{B}, \mathrm{D}, \mathrm{F}, \mathrm{H})$ are shown in Figure 6. Satt228 marker analysis showed the four female parents had the allele 1 (AA genotype) while the C242 male parent has the allele 2 (BB genotype). In seed, four parents had KTI protein and C242 had not KTI protein of $21.5 \mathrm{kDa}$. A total of $391 \mathrm{~F}_{5}$ plants derived from the four crosses (273 plants from Jinpunkong2 $\times$ C242, 17 plants from Hannamkong x C242, 45 plants from GS06 x C242, and 56 plants from $20 \mathrm{M} 183 \times$ C242) all have the allele 2 (BB genotype) for Satt228 marker. The 391 individual $\mathrm{F}_{6}$ seeds harvested from same individual $\mathrm{F}_{5}$ plants are also absent of the KTI protein. Complete cosegregation between the Satt228 marker allele and the Ti locus was observed in these four different populations (Kim et al., 2008).

\section{Conclusion}

Soybean Kunitz trypsin inhibitor (KTI) protein is a small, monomeric and non -glycosylated protein containing 181 amino acid residues and is responsible for the inferior nutritional quality of unheated or incompletely heated soybean meal. Ti gene controls the presence or absence of KTI protein. SSR marker tightly linked to the Ti locus was identified and was confirmed in two ways. Two mapping populations were developed. Population 1 was derived from a cross between cultivar Jinpumkong2 (TiTi) and C242 (titi). Population 2 was made from a mating between cultivar Clark (TiTi) and $\mathrm{C}_{242}$. Each $\mathrm{F}_{2}$ seed from $\mathrm{F}_{1}$ plants was analysed electrophoretically to determine the presence of the KTI protein band. Twelve DNA markers (4 RAPD, 4 AFLP, and 3 SSR) and Ti locus were found to be genetically linked in population 1 consisted with $94 \mathrm{~F}_{2}$ individual plants. Three SSR markers (Satt409, Satt228, and Satt429) were linked with $T i$ locus within $10 \mathrm{cM}$. Satt228 marker was tightly linked with Ti locus. Satt228 marker was tightly linked within $0-3.7 \mathrm{cM}$ of the Ti locus. Using several germplasms with TiTi or titi genotypes, Satt228 marker was confirmed. TiTi genotypes ('Jinpumkong2', 'Clark', and 'William') had allele1 and titi genotypes (PI196168, C242, W60 and PI157440) had allele2 in Satt228 marker analysis. 'Jinpumkong2', 'Clark', and 'William' (TiTi genotype) had Kunitz trypsin inhibitor protein of $21.5 \mathrm{kDa}$ size and PI196168, C242, W60, and PI157440 (titi genotype) did not have the band in protein gel electrophoresis from the mature seed. Cosegregation between KTI protein $(21.5 \mathrm{kDa}$ size) and allele of Satt228 marker was observed in seven germplasms with different genetic background. This result indicates that Satt228 marker may effectively utilized to select the plant with titi genotype. Also, Satt228 marker tightly linked to the Ti locus was confirmed in four different $\mathrm{F}_{5}$ populations. Four female parents (Glycine max L. cv. Jinpumkong2, Hannamkong, GS06, 20M183) of TiTi (KTI protein present) genotype and one male parent C242 of titi (KTI protein absent) genotype were used. Four different populations of $\mathrm{F}_{2}$ plants free of KTI protein were advanced to the $\mathrm{F}_{5}$ generation. Satt228 marker analysis showed the four female parents had the allele 1 (AA genotype) while the C242 male parent has the allele 2 (BB genotype). In seed, four parents had KTI protein and C242 had not KTI protein of $21.5 \mathrm{kDa}$. A total of $391 \mathrm{~F}_{5}$ plants derived from the four crosses (273 plants from Jinpunkong $2 \times \mathrm{C} 242$, 
17 plants from Hannamkong x C242, 45 plants from GS06 x C242, and 56 plants from $20 \mathrm{M} 183$ x C242) all have the allele 2 (BB genotype) for Satt228 marker. The 391 individual $\mathrm{F}_{6}$ seeds harvested from same individual $\mathrm{F}_{5}$ plants are also absent of the KTI protein. Complete cosegregation between the Satt228 marker allele and the Ti locus was observed in these four different populations. The objective of this research was to identify and to confirm a SSR marker tightly linked to the Ti locus for MAS breeding in different genetic populations and germplasms. So far, KTI free new soybean cultivars (Gaechuck\#1, Gaechuck\#2 and Jinnong\#1) have been developed using Satt228 marker.

\section{Acknowledgment}

Soybean genotype C242 and W60 was a generous gift from James E. Specht, professor of Agronomy, University of Nebraska-Lincoln, U.S.A.

\section{References}

Cregan, P.B., T. Jarvik, A.L. Bush, R.C. Shoemaker, K.G. Lark, A.L. Kahler, N. Kaya, T.T. VanToai, D.G. Lohnes, Jongil Chung \& J.E. Specht, 1999. An integrated genetic linkage map of the soybean genome. Crop Sci. 39:1464-1490.

Hidebrand, D.F., J.H. Orf \& T. Hymowitz. 1980. Inheritance of an acid phosphatase and its linkage with the Kunitz trypsin inhibitor in seed protein of soybeans. Crop Sci. 20: 83-85.

Hymowitz, T. \& H.H. Hadley, 1972. Inheritance of a trypsin inhibitor variant in seed protein of soybeans. Crop Sci. 12:197-198.

Kim, M.S., Y.J. Cho, D.J. Park, S.J. Han, J.H. Oh, J.G. Hwang, M.S. Ko \& J.I. Chung, 2003. Construction of genetic linkage map for korean soybean genotypes using molecular markers. KoreanJ. Crop Sci. 48(4):297-302.

Kim, MS, Hur MR, Jeong WH, Park MS, Lee KJ, Shim SI, Kim MC, Jung WS, Lee JH, and Chung JI. 2008. Confirmation of Satt228 marker tightly linked to the Ti locus in four different soybean populations. Genes \&Genomics 30(4):329-336.

Kiang, Y.T., 1987. Mapping three protein loci on a soybean chromosome. Crop Sci. 27: 44-46.

Kosambi, D.D., 1944. The estimation of map distance from recombinationAnn. Eugen. 12: 172-175.

Kunitz, M., 1945. Crystallization of a soybean trypsin inhibitor from soybean. Science 101:668-669.

Lander, E., P. Green, J. Abrahamson, A. Barlow, M.J. Daly, S.E. Lincoln \& L. Newburg, 1987. MAPMAKER: An interactive computer package forprimary genetic linkage maps of experiment and natural populations. Genomics 1:174-181.

Liencer, I.E. (1995) Possible adverse effects of soybean anticarcinogens. Journal of Nutrition 125: 744-750.

Michelmore, R.W., J. Paran \& R.V. Kesseli, 1991. Identification of markers linked to disease resistance genes by bulked segregant analysis: A rapid method to detect markers in specific genomic regions by using segregation populations. Proc. Natl. Acad. Sci. 88:9828-9832.

Moraes, R., Soares, T., Colombo, L., Salla, M., Barros, J., Piovesan, N., Barros, E. and Moreira, M. (2006)Assisted selection by specific DNA markers for genetic eliminationof the kunitz trypsin inhibitor and lectin in soybean seeds. Euphytica149:221-226. 
Orf, J.H., \& T. Hymowitz, 1979. Inheritance of the absence of the Kunitz trypsin inhibitor in seed protein of soybeans. Crop Sci. 19:107-109.

Palacios, M., Easter, R.A., Soltwedel, K.T., Parsons, C.M., Douglas, M.W. and Hymowitz, T. (2004) Effect of soybean variety and processing on growth performance of young chicks and pigs. Journal of Animal Science 82(4):1108-1114.

Saghai Maroof, M.A., K.M. Soliman, R.A. Jorgensen \& R.W. Allard, 1984.Ribosomal DNA spacer-length polymorphisms in barley: Mendelianchromosomal location and population dynamics. Proc. Natl. Acad. Sci. 81:8014-8018.

Sharp, P.J., Johnston, S., Brown, G., McIntosh, R.A., Pallotta, M., Carter, M., Bariana, H.S., Khartkar, S., Lagudah, E.S., Singh, R.P., Khairallah, M., Potter, R., Jones, M.G.K. 2001. Validation of molecular markers for wheat breeding. Aust J Agric Res 52:1357-1366.

Singh, L., C.M. Wilson \& H.H. Hadley, 1969. Genetic differences in soybean trypsin inhibitors separated by disc electrophoresis. Crop Sci. 9:489-491.

Song, S.I., Kim, C.H., Baek, S.J., Choi, Y.D. 1993. Nucleotide sequences of cDNAs encoding the precursors for soybean (Glycine max) trypsin inhibitors (Kunitz type). Plant Physiol. 101:1401-1402.

Vasconcelos, I.M., Maia, A.A.B., Siebra, E.A., Oliveira, J.T.A., Carvalho, A.F.F.U. and Melo, V.M.M. (2001) Nutritional study of two Brazilian soybean cultivars differing in the contents of antinutritional and toxic proteins. Journal of Nutritional Biochemistry 12(1):55-62.

Westfall, R.L., \& S.M. Hauge, 1948. The nutritive quality and the trypsin inhibitor content of soybean flour heated at various temperatures. J. Nutr. 35:379-389.

Wang, K.J., Yamashita, T., Watanabe, M., Takahata, Y. 2004. A Tib-derived variant of Kunitz trypsin inhibitor in wild soybean (Glycine soja). Genome 47:9-14. 


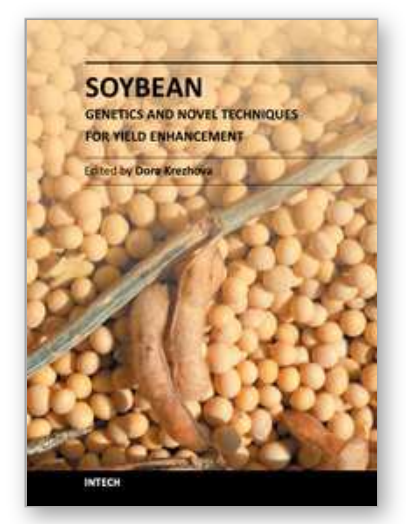

\author{
Soybean - Genetics and Novel Techniques for Yield Enhancement \\ Edited by Prof. Dora Krezhova
}

ISBN 978-953-307-721-5

Hard cover, 326 pages

Publisher InTech

Published online 07, November, 2011

Published in print edition November, 2011

This book presents the importance of applying of novel genetics and breading technologies. The efficient genotype selections and gene transformations provide for generation of new and improved soybean cultivars, resistant to disease and environmental stresses. The book introduces also a few recent modern techniques and technologies for detection of plant stress and characterization of biomaterials as well as for processing of soybean food and oil products.

\title{
How to reference
}

In order to correctly reference this scholarly work, feel free to copy and paste the following:

Jongil Chung (2011). Identification and Confirmation of SSR Marker Tightly Linked to the Ti Locus in Soybean [Glycine max (L.) Merr.], Soybean - Genetics and Novel Techniques for Yield Enhancement, Prof. Dora Krezhova (Ed.), ISBN: 978-953-307-721-5, InTech, Available from:

http://www.intechopen.com/books/soybean-genetics-and-novel-techniques-for-yield-

enhancement/identification-and-confirmation-of-ssr-marker-tightly-linked-to-the-ti-locus-in-soybean-glycine$\max -$

\section{INTECH}

open science | open minds

\section{InTech Europe}

University Campus STeP Ri Slavka Krautzeka 83/A 51000 Rijeka, Croatia Phone: +385 (51) 770447

Fax: +385 (51) 686166 www.intechopen.com

\section{InTech China}

Unit 405, Office Block, Hotel Equatorial Shanghai No.65, Yan An Road (West), Shanghai, 200040, China 中国上海市延安西路65号上海国际贵都大饭店办公楼 405 单元 Phone: $+86-21-62489820$

Fax: $+86-21-62489821$ 
(C) 2011 The Author(s). Licensee IntechOpen. This is an open access article distributed under the terms of the Creative Commons Attribution 3.0 License, which permits unrestricted use, distribution, and reproduction in any medium, provided the original work is properly cited. 